\title{
Heavy Metals in Native Potato and Health Risk Assessment in Highland Andean Zones of Junín, Peru
}

\author{
Edith Orellana ${ }^{1}$, María Carolina Bastos ${ }^{2}$, Walter Cuadrado ${ }^{1}$, Rosa Zárate ${ }^{1}$, \\ Vicky Sarapura', Luz Yallico', Fiorella Tabra', Diana Bao ${ }^{1}$ \\ ${ }^{1}$ Universidad Nacional del Centro del Perú, Huancayo, Perú \\ ${ }^{2}$ Centro Internacional de la Papa (CIP), Huancayo, Perú \\ Email: ^eporellana@uncp.edu.pe
}

How to cite this paper: Orellana, E., Bastos, M.C., Cuadrado, W., Zárate, R., Sarapura, V., Yallico, L., Tabra, F. and Bao, D. (2020) Heavy Metals in Native Potato and Health Risk Assessment in Highland Andean Zones of Junín, Peru. Journal of Environmental Protection, 11, 921-937. https://doi.org/10.4236/jep.2020.1111058

\section{Received: July 20, 2020}

Accepted: November 3, 2020

Published: November 6, 2020

Copyright $\odot 2020$ by author(s) and Scientific Research Publishing Inc. This work is licensed under the Creative Commons Attribution International License (CC BY 4.0).

http://creativecommons.org/licenses/by/4.0/

\begin{abstract}
Heavy metals are transferred from the abiotic environment to living organisms, accumulate in food, contaminate the food chain, and are an important route of human exposure involving a potential health risk. In this study, the concentrations of heavy metals $(\mathrm{Cd}, \mathrm{Fe}, \mathrm{Pb}, \mathrm{Zn}$ and $\mathrm{As})$ in agricultural soils and tubers of Solanum tuberosum spp. andigena (native potato) were evaluated. Also, an assessment of the health risk associated with the daily intake by the local population was performed in the four districts of the department of Junín, between altitudes of $3800 \mathrm{~m}$ to $4200 \mathrm{~m}$. The heavy metals concentrations in soils with native potato cultivation followed the following decreasing order of $\mathrm{Fe}>\mathrm{Zn}>\mathrm{Pb}>\mathrm{As}>\mathrm{Cd}$, with values below national standards. The heavy metals content in native potatoes was below the limits recommended by international standards with the exception of $\mathrm{Pb}$. The bioconcentration factor (BCF) for the two native potato varieties in decreasing order was $\mathrm{Zn}>$ $\mathrm{Cd}>\mathrm{Pb}>\mathrm{As}>\mathrm{Fe}$, all less than 0.5. The estimated daily intake of metals (EDIM) in adults and children through the consumption of native potatoes was higher for Fe and $\mathrm{Zn}$. The threshold carcinogenic risk values (TCR) for As exceeded the safety limits $1 \times 10^{-4}$. It is concluded that the residents in the four high Andean localities would be exposed to carcinogenic adverse health effects associated with the intake of native potatoes. It is important to monitor the concentration of As and other heavy metals in the Andean soils and crops in order to implement a soil and crop management program to ensure food quality.
\end{abstract}

\section{Keywords}

Bioconcentration Factor, Daily Intake, Non-Carcinogenic Risk, Carcinogenic 


\section{Introduction}

Heavy metals represent a source of contamination and an environmental and human health problem [1]. The soil is the entry point for heavy metals in plants and, consequently, also in the food chain [2]. There are different sources of heavy metals in the soil such as natural sources and anthropogenic sources (mining and industrial activities, irrigation with sewage and the excessive use of pesticides and fertilizers) [3] [4] [5]. Heavy metals contamination of agricultural soils is initiated by farmers, whose economic production depends on the use of agricultural chemicals and fertilizers and irrigation water [6]. Generally, the presence of these toxic elements in the soil and agricultural crops are associated with the use of fertilizers and the presence of ions that can bind these metals [7]. On the other hand, repeated applications of animal manure compost probably increase the concentrations of $\mathrm{Zn}, \mathrm{Cu}, \mathrm{Cd}$ and $\mathrm{Hg}$ in the soil [8] [9]. Pesticides also contain heavy metals such as $\mathrm{As}, \mathrm{Cr}, \mathrm{Co}, \mathrm{Pb}, \mathrm{Ni}[10]$ and these chemicals are used by farmers to control pests and diseases. Heavy metals are transferred from the abiotic environment to living organisms, accumulate in biota at different trophic levels, and therefore contaminate food chains with implications in human health and wildlife [11] [12]. Heavy metals presence such as $\mathrm{Cd}, \mathrm{Cr}, \mathrm{Cu}$, $\mathrm{Mn}, \mathrm{Ni}, \mathrm{Pb}$ and $\mathrm{Zn}$ in food is one of the most harmful health problems in the world due to its non-biodegradable nature, persistence and toxicity [13] [14] [15]. People are exposed to heavy metals and metalloids through ingestion, inhalation, and dermal contact [16]. Therefore, contamination of the food chain is one of the important pathways for the entry of these toxic contaminants in the human body which can cause health risks [17].

Health risks from heavy metals associated with the consumption of native potato is a very important issue, considering that Peru is the largest potato producer in Latin America and the twelfth in the world with 4.5 million tons per year [18]. Native potatoes represent a subsistence means for small farmers in the high Andean areas [19]. It is the main crop and a staple food of the high Andean population. In 2015, potato consumption in Peru reached $85 \mathrm{~kg} /$ person [20]. The native potato is cultivated in the mountains of Peru, especially in peasant communities above 3000 meters above sea level. Native potatoes have a high nutritional value, with a high content of proteins, vitamins C, B6, B1, folic acid, minerals such as potassium, phosphorus, calcium and magnesium, and micronutrients such as iron and zinc [21].

Some researchers from China, Pakistan and Slovakia have studied toxic metals in potatoes such as [22] [23] [24] [25]. They reported high contents of Cd and $\mathrm{Pb}$ in contaminated areas that in some cases exceeded the food safety standards. In Junín, Peru reported $\mathrm{Pb}$ contents in white or improved potatoes above rec- 
ommended limits [26]. In Peru, heavy metals contamination is a serious problem caused by mining activities leading to a chronic environmental impact due to the release of chemical residues, tailings, toxic gas, dust, acid drains and irreversible destruction of the ecosystem. In a nearby mining operation of La Oroya located in the central highlands, currently there are evidences for deterioration of water quality, air, soil, and fauna [27]; and is considered among the most dangerous for human health, due to their high concentrations of polluting and toxic products [28]. In this context, investigating the heavy metals content in native potatoes grown in Andean zones above $3800 \mathrm{~m}$ is a concern; considering it as a daily food for the Andean population. The objective of this research was to evaluate the concentrations of heavy metals in soil and accumulation in the tubers of two of native potato varieties ("peruanita" and "huayro macho") of major consumption, and to assess the potential of non-carcinogenic and carcinogenic risk in the health of the high Andean inhabitants from Junín department, Peru.

\section{Material and Methods}

\subsection{Study Area}

The study area is located in the central highlands of Peru, which includes the districts of Quilcas, Comas, Ricran and San Juan de Jarpa, within the provinces of Huancayo, Concepción, Jauja and Chupaca respectively, all located in the department of Junín (Figure 1). This area is one of the most representative for native potato cultivation and it is located at altitudes that range from 3000 to 4200 masl, between $11^{\circ} 32^{\prime} 26.855^{\prime \prime}$ and $12^{\circ} 8^{\prime} 5.525^{\prime \prime}$ south latitude; and $75^{\circ} 28^{\prime} 28.422^{\prime \prime}$ and $74^{\circ} 56^{\prime} 46.401^{\prime \prime}$ west longitude. The climate in this area is humid cold with maximum temperatures of $18^{\circ} \mathrm{C}$ to $24^{\circ} \mathrm{C}$ and minimum temperatures of $-5^{\circ} \mathrm{C}$ to $10^{\circ} \mathrm{C}$; with an annual precipitation that varies from 700 to $1170 \mathrm{~mm}$. The two native potato varieties "peruanita" and "huayro macho" are planted in a mixture, in rolling terrains with slopes of $30 \%$. The main economic activity of the families is agriculture and the raising of sheep, llamas and alpacas. Native potato production is for self-consumption and seed. A small portion of the production is sold in local markets and some in supermarkets, generating a small-scale income for rural families.

\subsection{Sample Preparation and Analysis}

At each locality, native potato plots under cultivation were selected. These were of variable size, ranging from $500 \mathrm{~m}^{2}$ to $1500 \mathrm{~m}^{2}$. With the participation of community members, in June 2019, at harvest, three plots were selected in the towns of Quilcas, Ricran and San Juan de Jarpa and four plots in the town of Comas. In each locality, three samples of native potatoes of $1 \mathrm{~kg}$ each of the "peruanita" variety and another three samples of $1 \mathrm{~kg}$ each of the "huayro macho" variety were collected. In total 26 samples of native potato tubers were collected. The samples were filled in craft paper bags, labeled and transported to the laboratory. The native potatoes were then washed three times with running 

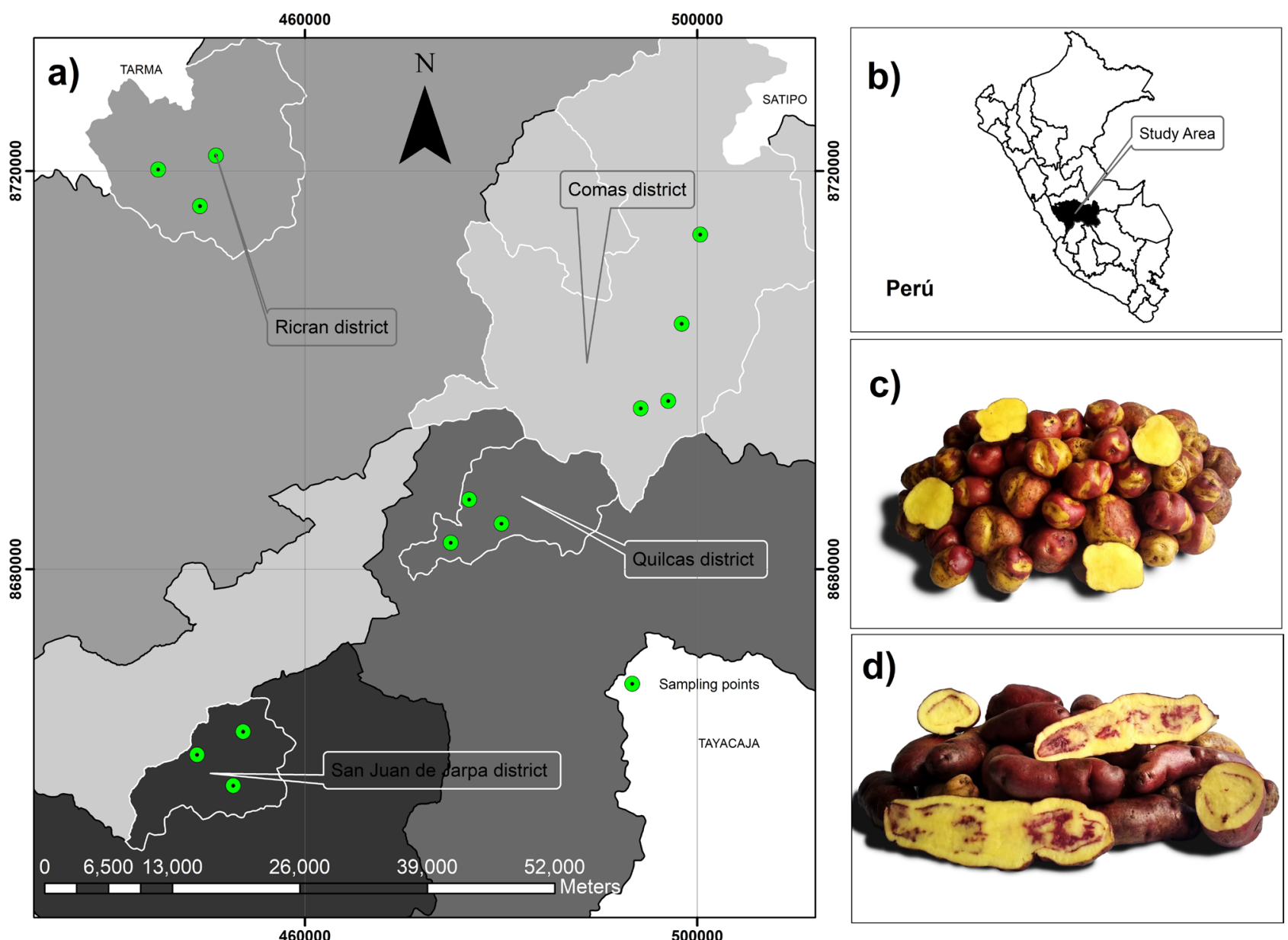

Figure 1. Sampling sites (a) y (b) of soils and two varieties of native potato: "peruanita" (c) and "huayro macho" (d) in four high Andean locations in Junín, Peru.

water to remove soil particles and surface contaminants, and rinsed with distilled water and subjected to a drying process at room temperature. Composite soil samples of $1 \mathrm{~kg}$ each were collected from the same selected plots, at a depth of 0 - $20 \mathrm{~cm}$. The soil samples were filled in hermetic polyethylene bags, labeled and transported to the laboratory. Previously, materials such as pebbles, small stones and organic remains were removed.

In the laboratory the digestion phase was carried out, previously the potatoes were chopped into small cubes of approximately $1 \mathrm{~cm}$, then they were taken to the drying oven at $60^{\circ} \mathrm{C}$ for five days until constant weight was obtained; once the samples were dry, they were sprayed with the mechanical spraying equipment with a zirconium grinding system. Similarly, approximately $100 \mathrm{~g}$ of soil samples were weighed, placed in containers, and dried at $60^{\circ} \mathrm{C}$ for $72 \mathrm{~h}$ until constant weight, sieved using a 20 mesh nylon screen. Then, with the help of a precision balance, $1 \mathrm{~g}$ of pulverized native potato of each of the varieties was weighed, and $0.5 \mathrm{~g}$ of sieved soil for each sampling point, all these samples were placed in beakers. The digestion phase was performed according to the procedure established by USEPA 3051 [29], the samples were transferred to $150 \mathrm{ml}$ 
beakers, $10 \mathrm{ml}$ of $\mathrm{HCl}$ and $3 \mathrm{ml}$ of $\mathrm{HNO}_{3}$ were added, the solutions were covered with clock moons and were subjected to $150^{\circ} \mathrm{C}$ until they become pasty, then the solution was cooled to room temperature, then the residues were diluted with deionized water after stirring, they were emptied into $100 \mathrm{ml}$ flasks, at they were then filtered with No. 42 filter paper and the samples were stored in the refrigerator at $4^{\circ} \mathrm{C}$ before analysis. The heavy metals concentrations were determined using the atomic absorption spectrophotometer (Varian Model AA240). Before the analysis of the metals, the instrument was calibrated using standard solutions, which were supplied by Merck to establish the standard calibration curves for each metal.

\subsection{Questionnaire}

A questionnaire was developed to determine the average daily intake rates of native potato by the inhabitants of each study place. A questionnaire was applied to 65 peasant families in order to extract information on the amount of native potato intake per day, frequency of intake, age and weight of children and adults. A representative of each family among men and women over 18 years of age in the four localities were surveyed.

\subsection{Bioconcentration Factor}

The bioconcentration factor (BCF) measures the translocation capacity of the heavy metals from the soil to the edible part of the crop plants [30]. Metal concentrations in the soil and tubers were calculated on the basis of their fresh weight. The $\mathrm{BCF}$ of $\mathrm{As}, \mathrm{Cd}, \mathrm{Fe}, \mathrm{Pb}$ and $\mathrm{Zn}$ were calculated using the following Equation (1) [31] [32]:

$$
\mathrm{BCF}=\frac{\text { Cpotato }}{\text { Csoil }}
$$

where Cpotato and Csoil represent heavy metals concentrations in native potato tubers and soil samples in $\mathrm{mg} / \mathrm{kg}$ respectively.

\subsection{Human Health Risk Assessment}

Human health risk assessment is a common method of quantifying the nature and likelihood of adverse health effects in humans who are exposed to certain heavy metals [33]. To assess the risk to human health of heavy metals, the level of human exposure to this metal should be calculated following the route of exposure of the contaminant to the human body:

\section{Daily Metal Intake (EDIM)}

The estimated daily intake of metals (EDIM) through food was calculated using the following Equation (2) [34] [35] [36]:

$$
\mathrm{EDIM}=\frac{\mathrm{Cm} \times \mathrm{Cf} \times \mathrm{IR}}{\mathrm{BW}}
$$

where EDIM represents the estimated daily intake of metals $(\mathrm{mg} / \mathrm{kg} / \mathrm{day}), \mathrm{Cm}$ is the concentration of the metal in the tuber $(\mathrm{mg} / \mathrm{kg})$, Cf is the conversion factor 
from fresh weight to dry weight of vegetables (0.085) [37] [38], IR is the daily intake rate of native potato from tubers ( $\mathrm{kg} / \mathrm{day} /$ person). According to the questionnaire carried out in the four localities, the average daily intake of native potatoes between "peruanita" and "huayro macho" potatoes was $165.1 \pm 59.1 \mathrm{~g} /$ day for children and $468.4 \pm 126.7 \mathrm{~g} /$ day for adults. BW is the average body weight $(\mathrm{kg})$. The average body weight for children was $18.3 \pm 2.2 \mathrm{~kg}$ and for adults was $64.5 \pm 10.2 \mathrm{~kg}$.

\section{Non-Carcinogenic Risk Assessment}

Non-cancerous risks are assumed to exhibit a threshold below which adverse effects on human health are not expected to be a concern [39]. The health risk caused by exposure to non-carcinogenic heavy metals from food intake was calculated by the threshold hazard quotient (THQ). THQ for each metal was calculated according to the following Equation (3) [35] [36]:

$$
\mathrm{THQ}=\frac{\mathrm{C} \times \mathrm{IR} \times \mathrm{EF} \times \mathrm{ED}}{\mathrm{RfD} \times \mathrm{BW} \times \mathrm{ATn}}
$$

where: $\mathrm{C}$ is the concentration of heavy metals in the tuber $(\mathrm{mg} / \mathrm{kg})$; IR is the daily intake of native potato $(0.165 \mathrm{~kg} /$ day for children and $0.468 \mathrm{~kg} /$ day for adults); EF is the frequency of exposure (365 days/year); ED is the duration of exposure (70 years) equivalent to the average life span [30] [40]; RfD becomes the reference oral dose. The RfD values for $\mathrm{As}, \mathrm{Cd}, \mathrm{Fe}, \mathrm{Pb}$ and $\mathrm{Zn}$ are 0.0003, $0.001,0.7,0.0035$ and $0.30 \mathrm{mg} / \mathrm{kg} /$ day respectively [41] [42]. BW is the average body weight (18.3 $\mathrm{kg}$ for children and $64.5 \mathrm{~kg}$ for adults); ATn is the average time of exposure to non-carcinogenic heavy metals ( $\mathrm{ED} \times 365$ days/year).

To assess the general non-carcinogenic effects of all heavy metals, the THQs were added and it was expressed as the hazard index (HI) according to Equation (4):

$$
\mathrm{HI}=\sum \mathrm{THOi}=\mathrm{THQAs}+\mathrm{THQCd}+\mathrm{THQFe}+\mathrm{THQPb}+\mathrm{THQZn}
$$

where THQi is the objective risk quotient of an individual metal element, $\mathrm{HI}$ is the total risk index for the five metals studied. If the THQ or HI values are $<1$, it is assumed that there is no significant risk of a non-carcinogenic effect, therefore it is assumed that this index is safe throughout life; otherwise, if the THQ or HI values are $\geq 1$ it could represent a greater probability of a non-carcinogenic adverse effect for health [38] [43].

\section{Carcinogenic Risk Assessment}

Threshold carcinogenic risk (TCR) is a parameter used to determine the probability that an individual will develop cancer throughout life due to exposure to carcinogens [35]. The TCR of the carcinogenic heavy metals (As, Cd and $\mathrm{Pb}$ ) was calculated using Equation (5) [36]:

$$
\mathrm{TCR}=\frac{\mathrm{C} \times \mathrm{IR} \times \mathrm{EF} \times \mathrm{ED} \times \mathrm{CPSo}}{\mathrm{BW} \times \mathrm{ATc}}
$$

where: ATc is the average time for carcinogens $(70 \times 365$ days); CPSo is the oral carcinogenic risk factor for metals, according to the Integrated Risk Information 
System database [42]. The carcinogenic risk factor for inorganic As is 1.5 $\mathrm{mg} / \mathrm{kg} / \mathrm{day}$; for $\mathrm{Cd}$ and $\mathrm{Pb}$ are of $0.6 \mathrm{mg} / \mathrm{kg} /$ day and $0.0085 \mathrm{mg} / \mathrm{kg} /$ day respectively [44]. C, IR, EF, ED and BW were previously described. The acceptable range of the TCR value is between $1 \times 10^{-6}-1 \times 10^{-4}$, if the TCR threshold value is below $1 \times 10^{-6}$, it is accepted that there are no significant risks to human health, and if the TCR threshold value exceeds $1 \times 10^{-4}$ indicates a potential lifetime carcinogenic risk [45].

\subsection{Statistical Analysis}

Means, standard deviations, minimum and maximum values of heavy metals concentrations in soil and tuber samples were calculated. The two-way ANOVA was used to detect significant differences in heavy metals concentrations between varieties and localities, and the comparison of means was performed using the Tukey test with a significance level of 0.05 .

\section{Results and Discussion}

\subsection{Concentration of Heavy Metals in Soils}

The concentrations of heavy metals in soil samples obtained from native potato fields are presented in Table 1. The concentrations of selected metals in the soil ranged from 0.194 to $30,658.58 \mathrm{mg} / \mathrm{kg}$ throughout the study area, and in a decreasing order as follows: $\mathrm{Fe}>\mathrm{Zn}>\mathrm{Pb}>\mathrm{As}>\mathrm{Cd}$. The average concentrations of specific heavy metals in soil samples ranged from $4.92-15.85,0.19-0.40,9.0$ 44.82, 18,205.6 - 30,658.6 and 73.24 - $109.26 \mathrm{mg} / \mathrm{kg}$ for As, Cd, Pb, Fe and Zn respectively. The values of $\mathrm{As}, \mathrm{Cd}, \mathrm{Pb}$ and $\mathrm{Zn}$ in the soil did not exceed the limits observed by Peruvian regulations [46] and that established by China [22]. However, significant variations in the content of metals in the soil were observed between the places studied. Higher concentrations of $\mathrm{As}, \mathrm{Pb}, \mathrm{Fe}$ and $\mathrm{Zn}$ were observed in the following order: Quilcas $>$ Ricrán $>$ Jarpa $>$ Comas. The presence

Table 1. Heavy metals concentrations in soil samples $(\mathrm{mg} / \mathrm{kg})$ from native potato fields in four highland Andean locations in Junín, Peru.

\begin{tabular}{cccccc}
\hline Sampling sites & As & Cd & Pb & Fe & Zn \\
\hline Jarpa & $7.975 \pm 2.682^{\mathrm{bc}}$ & $0.403 \pm 0.129^{\mathrm{a}}$ & $32.381 \pm 4.396^{\mathrm{a}}$ & $18,205.66 \pm 2999.75^{\mathrm{a}}$ & $75.12 \pm 10.156^{\mathrm{a}}$ \\
Quilcas & $15.849 \pm 3.52^{\mathrm{a}}$ & $0.347 \pm 0.035^{\mathrm{a}}$ & $44.823 \pm 11.859^{\mathrm{a}}$ & $30,658.58 \pm 6508.84^{\mathrm{b}}$ & $109.26 \pm 9.64^{\mathrm{b}}$ \\
Ricran & $12.499 \pm 3.135^{\mathrm{ab}}$ & $0,334 \pm 0.058^{\mathrm{ab}}$ & $34.763 \pm 9.352^{\mathrm{a}}$ & $23,158.23 \pm 4607.49^{\mathrm{ab}}$ & $76.21 \pm 11.63^{\mathrm{a}}$ \\
Comas & $4.915 \pm 1.90^{\mathrm{c}}$ & $0.194 \pm 0.04^{\mathrm{b}}$ & $9.003 \pm 4.275^{\mathrm{b}}$ & $26,745.75 \pm 5544.78^{\mathrm{ab}}$ & $73.24 \pm 19.45^{\mathrm{a}}$ \\
Average & $9.894 \pm 5.189$ & $0.310 \pm 0.110$ & $28.609 \pm 16.241$ & $24,850.03 \pm 6743.58$ & $82.67 \pm 20.260$ \\
Mínimum & 2.597 & 0.143 & 4.670 & $14,624.00$ & 44.17 \\
Máximum & 19.986 & 0.567 & 59.590 & $38,789.25$ & 118.49 \\
MAL & $50^{\mathrm{a}}$ & $14^{\mathrm{a}}$ & $70^{\mathrm{a}}$ & $50,000.00^{\mathrm{b}}$ & $300^{\mathrm{b}}$
\end{tabular}

Different lowercase letters denote significant difference $(\mathrm{p}<0.05)$. MAL (Maximum allowable limits) according to ${ }^{\mathrm{a}}[46]$ and $\mathrm{b}[22]$. 
of these chemical elements in the soil could be attributed to the application of inorganic and organic fertilizers (manure) and pesticides to the potato crop [1] [10] [47] and to air pollution [48]. Therefore, it is very important to determine the sources, distribution and level of contamination of the high Andean soils.

\subsection{Accumulation of Heavy Metals in Native Potato Tubers}

Table 2 shows the results of the heavy metals content in tubers of both native potato varieties collected in the four districts and obtained from the same soil sampling sites. Values obtained were compared to the maximum levels recommended by the Food and Agriculture Organization and World Health Organization (FAO/WHO) [49] and to that established by the Republic of China [22]. The mean $\mathrm{Pb}$ concentrations ranged from $0.203 \mathrm{mg} / \mathrm{kg}-0.860 \mathrm{mg} / \mathrm{kg}$ which were above the maximum recommended values $(0.1 \mathrm{mg} / \mathrm{kg})$ in the four locations, while the content of As, $\mathrm{Cd}, \mathrm{Fe}$ and $\mathrm{Zn}$ did not exceed the maximum recommended limits. Significant differences were observed in the concentrations of $\mathrm{Pb}$ and Fe between potato varieties "peruanita" and "huayro macho" ( $\mathrm{p}<0.05)$, with higher concentrations in the variety "huayro macho". In addition, significant differences were detected in the content of heavy metals between the four districts $(\mathrm{p}<0.05)$. Higher contents of $\mathrm{Pb}, \mathrm{Fe}$ and $\mathrm{Zn}$ were detected in tubers from the Comas district. The heavy metals levels in native potatoes followed the following decreasing order $\mathrm{Fe}>\mathrm{Zn}>\mathrm{Pb}>\mathrm{As}>\mathrm{Cd}$ for both varieties. The levels of $\mathrm{Fe}$ and $\mathrm{Zn}$ were the highest. Similar studies performed in China, indicate higher Cd contents in potatoes above the recommended limits [23] [25], while in

Table 2. Heavy metals concentrations in tubers of two native potato varieties $(\mathrm{mg} / \mathrm{kg})$ in four highland Andean locations in Junín, Peru.

\begin{tabular}{ccccccc}
\hline Sampling sites & Potato varieties & As & Cd & Pb & Fe & Zn \\
\hline Jarpa & "peruanita" & $0.05 \pm 0.028^{\mathrm{a}}$ & $0.076 \pm 0.013^{\mathrm{a}}$ & $0.203 \pm 0.185^{\mathrm{a}}$ & $38.783 \pm 8.875^{\mathrm{a}}$ & $14.082 \pm 3.459^{\mathrm{a}}$ \\
& "huayro macho" & $0.0993 \pm 0.086^{\mathrm{a}}$ & $0.053 \pm 0.005^{\mathrm{a}}$ & $0.3587 \pm 0.21^{\mathrm{b}}$ & $78.93 \pm 15.60^{\mathrm{b}}$ & $14.47 \pm 2.83^{\mathrm{a}}$ \\
& Average & $0.0777^{\mathrm{a}}$ & $0.0648^{\mathrm{b}}$ & $0.2807^{\mathrm{ab}}$ & $58.86^{\mathrm{b}}$ & $14.27^{\mathrm{a}}$ \\
Quilcas & "peruanita" & $0.1347 \pm 0.014^{\mathrm{a}}$ & $0.0217 \pm 0.004^{\mathrm{a}}$ & $0.3497 \pm 0.108^{\mathrm{a}}$ & $116.33 \pm 3.51^{\mathrm{a}}$ & $13.03 \pm 3.15^{\mathrm{a}}$ \\
& "huayro macho" & $0.2423 \pm 0.073^{\mathrm{a}}$ & $0.0553 \pm 0.019^{\mathrm{a}}$ & $0.8600 \pm 0.330^{\mathrm{b}}$ & $147.67 \pm 32.52^{\mathrm{b}}$ & $17.50 \pm 4.52^{\mathrm{a}}$ \\
& Average & $0.1885^{\mathrm{b}}$ & $0.0385^{\mathrm{a}}$ & $0.6048^{\mathrm{b}}$ & $132.00^{\mathrm{c}}$ & $15.27^{\mathrm{ab}}$ \\
Ricran & "peruanita" & $0.1342 \pm 0.039^{\mathrm{a}}$ & $0.0410 \pm 0.006^{\mathrm{a}}$ & $0.1317 \pm 0.131^{\mathrm{a}}$ & $5.25 \pm 2.20^{\mathrm{a}}$ & $19.73 \pm 10.02^{\mathrm{a}}$ \\
& "huayro macho" & $0.0373 \pm 0.014^{\mathrm{a}}$ & $0.0223 \pm 0.008^{\mathrm{a}}$ & $0.0693 \pm 0.084^{\mathrm{b}}$ & $5.64 \pm 3.37^{\mathrm{b}}$ & $17.03 \pm 6.13^{\mathrm{a}}$ \\
& Average & $0.0858^{\mathrm{a}}$ & $0.0317^{\mathrm{a}}$ & $0.1005^{\mathrm{a}}$ & $5.44^{\mathrm{a}}$ & $18.38^{\mathrm{ab}}$ \\
Comas & "peruanita" & $0.1842 \pm 0.018^{\mathrm{a}}$ & $0.0376 \pm 0.007^{\mathrm{a}}$ & $0.5422 \pm 0.265^{\mathrm{a}}$ & $135.60 \pm 18.32^{\mathrm{a}}$ & $26.41 \pm 5.35^{\mathrm{a}}$ \\
& "huayro macho" & $0.1080 \pm 0.014^{\mathrm{a}}$ & $0.0347 \pm 0.005^{\mathrm{a}}$ & $0.7100 \pm 0.21^{\mathrm{b}}$ & $200.67 \pm 59.53^{\mathrm{b}}$ & $18.31 \pm 1.23^{\mathrm{a}}$ \\
& Average & $0.1556^{\mathrm{ab}}$ & $0.0365^{\mathrm{a}}$ & $0.6051^{\mathrm{b}}$ & $160.00^{\mathrm{c}}$ & $23.37^{\mathrm{b}}$
\end{tabular}

Different lowercase letters denote significant difference $(\mathrm{p}<0.05)$. MAL (Maximum Allowable Limits) according to ${ }^{\mathrm{a}}[49]$ and ${ }^{\mathrm{b}}[22]$. 
Slovakia and Jamaica report indicate lower values [2] [50] coincident with what was found in this study. In Punjab, Pakistan [22] reports indicate high Pb contents in potato that exceed 40 times the allowed limit, while our study determined that $\mathrm{Pb}$ exceeds four times what is recommended.

The bioconcentration factor (BCF) measures the ability of metals to move from the soil to the tuber, BCF of heavy metals in the tubers is shown in Figure 2. BCF values were higher for $\mathrm{Cd}$ and $\mathrm{Zn}$ compared to the other metals studied because these elements are readily absorbed, especially Cd element [51]. No significant differences in $\mathrm{BCF}$ were observed for $\mathrm{As}, \mathrm{Cd}, \mathrm{Pb}$ and $\mathrm{Zn}$ between the two varieties of native potato except for Fe. The highest $\mathrm{BCF}$ value was registered for Fe in the "huayro macho" variety. The sequence of BCF values for metals in native potato was found in the following decreasing order: $\mathrm{Zn}>\mathrm{Cd}>\mathrm{Pb}>\mathrm{As}>$ Fe; with means of $0.241,0.147,0.031,0.018$ and 0.004 respectively. The two varieties of native potato "peruanita" and "huayro macho" were not enriched with the metals under study because the BCF values were less than 1 , and these results are coincident with the results found in China and Jamaica [23] [50]. In the Comas district, the two varieties of native potato showed higher BCF for the five metals, this could probably be due to variations in the physical and chemical properties of the soil, the environmental conditions of each site and the chemical form of the metal that determines the mobilization and transfer of metals [51] [52].
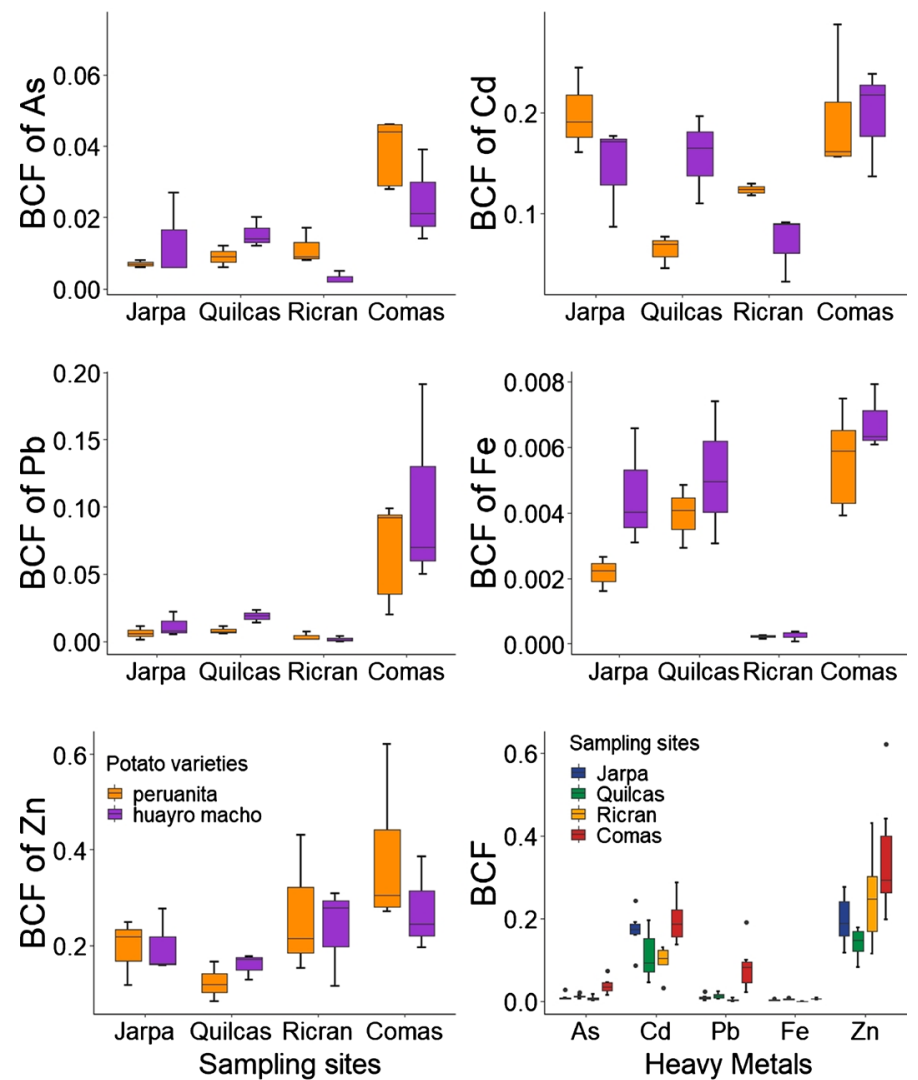

Figure 2. Bioconcentration Factors (BCF) of heavy metals in two native potato varieties and four highland Andean locations in Junín, Peru. 


\subsection{Estimated Daily Intake of Metals}

When estimating the levels of exposure to heavy metals in the human population is very important to assess the health risk of any contaminant in the daily intake of food. The estimated daily intake of metals (EDIM) in adults and children in the four districts is shown in Table 3. The daily intake of $\mathrm{Zn}$ and Fe was higher in children $(0.068$ and $0.014 \mathrm{mg} / \mathrm{kg} /$ day $)$ than in adults $(0.047$ and 0.011 $\mathrm{mg} / \mathrm{kg} /$ day). These results were lower than the reference doses (0.7 and 0.30 $\mathrm{mg} / \mathrm{kg} /$ day). A study in Pakistan found similar results in potatoes [22]. The decreasing order of daily heavy metals intake for children and adults was as follows: $\mathrm{Fe}>\mathrm{Zn}>\mathrm{Pb}>\mathrm{As}>\mathrm{Cd}$ with values less than 0.1. In a nearby area of $\mathrm{Zn}$ smelting facility in China, values less than 0.01 were reported in potato intake [23]. The daily intake of heavy metals was below the provisional maximum tolerable daily intake (PMTDI) for $\mathrm{Fe}(0.8 \mathrm{mg} / \mathrm{kg} /$ day $)$ and $\mathrm{Zn}(0.3-1.0$ $\mathrm{mg} / \mathrm{kg} /$ day) and tolerable weekly intake provisional (PTWI) for As $(0.015$ $\mathrm{mg} / \mathrm{kg}), \mathrm{Cd}(0.007 \mathrm{mg} / \mathrm{kg})$ and $\mathrm{Pb}(0.025 \mathrm{mg} / \mathrm{kg})$ as recommended by Food and Agriculture Organization and World Health Organization (FAO/WHO) [53] [54] [55]. Therefore, we can safely assume that there is not a health risk for native potato consumers. The $\mathrm{Fe}$ and $\mathrm{Zn}$ contents in native potatoes are essential trace elements required by humans in essential biochemical processes, and they are not a threat when the intake is within the permitted limits.

\subsection{Non-Carcinogenic and Carcinogenic Risk of Heavy Metals}

Threshold hazard quotient (THQ) values for the individual heavy metals through the consumption of native potatoes are shown in Table 4. In children, the average THQ values for $\mathrm{As}, \mathrm{Cd}, \mathrm{Pb}, \mathrm{Fe}$, and $\mathrm{Zn}$ were 0.324, 0.033, 0.087, 0.098 and 0.046 respectively; and in adults these values were $0.261,0.027,0.070$, 0.079 and 0.037 . Comparing to similar studies elsewhere, these values were higher than what was found in China [23]. The THQ for the adult and child

Table 3. Estimated daily intake of metals (EDIM) in children and adults in four highland Andean locations in Junín, Peru.

\begin{tabular}{ccccccc}
\hline \multirow{2}{*}{ EDIM } & Sampling sites & As & Cd & Pb & Fe & Zn \\
\hline Children & Jarpa & $5.96 \mathrm{E}-05$ & $4.97 \mathrm{E}-05$ & $2.15 \mathrm{E}-04$ & $4.51 \mathrm{E}-02$ & $1.09 \mathrm{E}-02$ \\
& Quilcas & $1.45 \mathrm{E}-04$ & $2.95 \mathrm{E}-05$ & $4.64 \mathrm{E}-04$ & $1.01 \mathrm{E}-01$ & $1.17 \mathrm{E}-02$ \\
& Ricran & $6.58 \mathrm{E}-05$ & $2.43 \mathrm{E}-05$ & $7.71 \mathrm{E}-05$ & $4.17 \mathrm{E}-03$ & $1.41 \mathrm{E}-02$ \\
& Comas & $1.19 \mathrm{E}-04$ & $2.80 \mathrm{E}-05$ & $4.64 \mathrm{E}-04$ & $1.23 \mathrm{E}-01$ & $1.79 \mathrm{E}-02$ \\
& Average & $9.73 \mathrm{E}-05$ & $3.29 \mathrm{E}-05$ & $3.05 \mathrm{E}-04$ & $6.83 \mathrm{E}-02$ & $1.37 \mathrm{E}-02$ \\
& Jarpa & $4.79 \mathrm{E}-05$ & $4.00 \mathrm{E}-05$ & $1.73 \mathrm{E}-04$ & $7.85 \mathrm{E}-03$ & $8.81 \mathrm{E}-03$ \\
& Quilcas & $1.16 \mathrm{E}-04$ & $2.38 \mathrm{E}-05$ & $3.73 \mathrm{E}-04$ & $8.15 \mathrm{E}-02$ & $9.42 \mathrm{E}-03$ \\
& Ricran & $5.29 \mathrm{E}-05$ & $1.95 \mathrm{E}-05$ & $6.20 \mathrm{E}-05$ & $3.36 \mathrm{E}-03$ & $1.13 \mathrm{E}-02$ \\
& Comas & $9.61 \mathrm{E}-05$ & $2.25 \mathrm{E}-05$ & $3.74 \mathrm{E}-04$ & $9.88 \mathrm{E}-02$ & $1.44 \mathrm{E}-02$ \\
& Average & $7.83 \mathrm{E}-05$ & $2.65 \mathrm{E}-05$ & $2.46 \mathrm{E}-04$ & $4.79 \mathrm{E}-02$ & $1.10 \mathrm{E}-02$ \\
\hline
\end{tabular}


Table 4. Non-carcinogenic risk (Threshold hazard quotient, THQ), overall toxic risk (Hazard Index, HI) and Threshold carcinogenic risk (TCR) of heavy metals in native potato in four highland Andean locations in Junín, Peru.

\begin{tabular}{|c|c|c|c|c|c|c|c|c|c|c|}
\hline & \multirow{2}{*}{$\begin{array}{l}\text { Sampling } \\
\text { sites }\end{array}$} & \multicolumn{5}{|c|}{ THQ } & \multirow{2}{*}{ HI } & \multicolumn{3}{|c|}{ TCR } \\
\hline & & As & $\mathrm{Cd}$ & $\mathrm{Pb}$ & $\mathrm{Fe}$ & $\mathrm{Zn}$ & & As & $\mathrm{Cd}$ & $\mathrm{Pb}$ \\
\hline \multirow[t]{5}{*}{ Children } & Jarpa & $1.99 \mathrm{E}-01$ & $4.97 \mathrm{E}-02$ & $6.15 \mathrm{E}-02$ & $6.45 \mathrm{E}-02$ & $3.65 \mathrm{E}-02$ & $4.11 \mathrm{E}-01$ & $8.94 \mathrm{E}-05$ & $2.98 \mathrm{E}-05$ & $1.83 \mathrm{E}-06$ \\
\hline & Quilcas & $4.82 \mathrm{E}-01$ & $2.95 \mathrm{E}-02$ & $1.33 \mathrm{E}-01$ & $1.45 \mathrm{E}-01$ & $3.90 \mathrm{E}-02$ & $8.28 \mathrm{E}-01$ & $2.17 \mathrm{E}-04$ & $1.77 \mathrm{E}-05$ & $3.94 \mathrm{E}-06$ \\
\hline & Ricrán & $2.19 \mathrm{E}-01$ & $2.43 \mathrm{E}-02$ & $2.20 \mathrm{E}-02$ & $5.96 \mathrm{E}-03$ & $4.70 \mathrm{E}-02$ & $3.19 \mathrm{E}-01$ & $9.87 \mathrm{E}-05$ & $1.46 \mathrm{E}-05$ & $6.55 \mathrm{E}-07$ \\
\hline & Comas & $3.98 \mathrm{E}-01$ & $2.80 \mathrm{E}-02$ & $1.33 \mathrm{E}-01$ & $1.75 \mathrm{E}-01$ & $5.97 \mathrm{E}-02$ & $7.93 \mathrm{E}-01$ & $1.79 \mathrm{E}-04$ & $1.68 \mathrm{E}-05$ & $3.94 \mathrm{E}-06$ \\
\hline & Average & $3.24 \mathrm{E}-01$ & $3.29 \mathrm{E}-02$ & $8.72 \mathrm{E}-02$ & $9.76 \mathrm{E}-02$ & $4.56 \mathrm{E}-02$ & $2.63 \mathrm{E}-01$ & $1.46 \mathrm{E}-04$ & $1.97 \mathrm{E}-05$ & $2.59 \mathrm{E}-06$ \\
\hline \multirow[t]{5}{*}{ Adults } & Jarpa & $1.60 \mathrm{E}-01$ & $4.00 \mathrm{E}-02$ & $4.95 \mathrm{E}-02$ & $5.19 \mathrm{E}-02$ & $2.94 \mathrm{E}-02$ & $3.31 \mathrm{E}-01$ & $7.19 \mathrm{E}-05$ & $2.40 \mathrm{E}-05$ & $3.94 \mathrm{E}-06$ \\
\hline & Quilcas & $3.88 \mathrm{E}-01$ & $2.38 \mathrm{E}-02$ & $1.07 \mathrm{E}-01$ & $1.16 \mathrm{E}-01$ & $3.14 \mathrm{E}-02$ & $6.66 \mathrm{E}-01$ & $1.75 \mathrm{E}-04$ & $1.43 \mathrm{E}-05$ & $6.55 \mathrm{E}-07$ \\
\hline & Ricrán & $1.77 \mathrm{E}-01$ & $1.96 \mathrm{E}-02$ & $1.77 \mathrm{E}-02$ & $4.80 \mathrm{E}-03$ & $3.78 \mathrm{E}-02$ & $2.56 \mathrm{E}-01$ & $7.94 \mathrm{E}-05$ & $1.17 \mathrm{E}-05$ & $3.94 \mathrm{E}-06$ \\
\hline & Comas & $3.20 \mathrm{E}-01$ & $2.25 \mathrm{E}-02$ & $1.07 \mathrm{E}-01$ & $1.41 \mathrm{E}-01$ & $4.81 \mathrm{E}-02$ & $6.39 \mathrm{E}-01$ & $1.44 \mathrm{E}-04$ & $1.35 \mathrm{E}-05$ & $1.18 \mathrm{E}-04$ \\
\hline & Average & $2.61 \mathrm{E}-01$ & $2.65 \mathrm{E}-02$ & $7.02 \mathrm{E}-02$ & $7.85 \mathrm{E}-02$ & $3.67 \mathrm{E}-02$ & $2.12 \mathrm{E}-01$ & $1.17 \mathrm{E}-04$ & $1.59 \mathrm{E}-05$ & $2.09 \mathrm{E}-06$ \\
\hline
\end{tabular}

population was less than 1, suggesting an acceptable level of non-carcinogenic adverse health risk for all heavy metals. The THQ values of heavy metals studied in native potato for children and adults were found in the following order: As > $\mathrm{Fe}>\mathrm{Pb}>\mathrm{Zn}>\mathrm{Cd}$. Higher THQ values were observed in children than in adults, which is consistent with previous studies [41] [56] [57]. This indicates that children have a greater probability of health risk than adults. Children are more vulnerable to dangerous toxic elements because gastrointestinal absorption is higher in children compared to adults, possibly due to physiological differences in diet intake and nutrition [58]. In the Comas and Quilcas districts, higher THQ values for $\mathrm{As}, \mathrm{Pb}$ and $\mathrm{Fe}$ were observed in children and adults, a result that could be explained to the concentration levels of these metals in tubers of the two native potato varieties and the amounts of consumption.

Hazard index (HI) values ranged from 0.319 to 0.828 for children and from 0.256 to 0.666 for adults, with values below 1 . Therefore, we can assume that the exposed population experiences a low risk [31], indicating potato consumption in the area is safe. Even though, high THQ values were detected for some elements such as As; and $\mathrm{Pb}$ exceeds permissible limit values, we can state that the population of the four areas under study does not present a significant non-carcinogenic potential health risk from native potato consumption.

$\mathrm{As}, \mathrm{Cd}$ and $\mathrm{Pb}$ are considered carcinogenic to humans through oral ingestion [58], so it was necessary to calculate the carcinogenic risk of exposure by ingestion of native potato. The threshold carcinogenic risk (TCR) values of As, Cd and $\mathrm{Pb}$ were generally higher in children than in adults, values consistent with that reported by [33]. The TCR value of As ranged from $8.94 \times 10^{-5}$ to $2.17 \times$ $10^{-4}$ in children and from $7.19 \times 10^{-5}$ to $1.75 \times 10^{-4}$ in adults. Average TCR values of $\mathrm{Cd}$ and $\mathrm{Pb}$ in children were $1.97 \times 10^{-5}$ and $2.59 \times 10^{-6}$ respectively and in adults were $1.59 \times 10^{-5}$ and $2.09 \times 10^{-6}$ respectively (Table 4 ). The decreasing 
order of TCR was $\mathrm{As}>\mathrm{Cd}>\mathrm{Pb}$ for children and adults, the acceptable range of carcinogenic risk (TCR) of heavy metals in food is between $1 \times 10^{-6}-1 \times 10^{-4}$ [36] [56]. The TCR values of As were greater than the critical value of $1 \times 10^{-4}$ for children and adults, therefore they were not within the safe range, which means that the intake of native potatoes represents a lifetime cancer risk for children and adults associated with the ingestion of contaminated foods with this toxic element. In the town of Quilcas, higher TCR values were found for the three metals, which would be associated with excessive and prolonged consumption of native potatoes. The finding of these results is of concern about the possible cancer risk of As for residents in the four districts studied in the Junín region, considering that As can cause skin, bladder and lung cancers [59].

\section{Conclusion}

The highest concentrations of heavy metals in agricultural soils of four highland Andean locations in Peru were observed for $\mathrm{Fe}$, with a decreasing order of other heavy metals: $\mathrm{Zn}>\mathrm{Pb}>\mathrm{As}>\mathrm{Cd}$. The contents of the selected heavy metals in native potatoes were below the safe limits with exception of $\mathrm{Pb}$. The bioconcentration factor trend for the two native potato varieties was in the following order: $\mathrm{Zn}>\mathrm{Cd}>\mathrm{Pb}>\mathrm{As}>\mathrm{Fe}$. The estimated daily intake of metals in adults and children through the consumption of native potato was higher for $\mathrm{Fe}$ and $\mathrm{Zn}$. The hazard index and threshold hazard quotient values of heavy metals were found within the safety limits. Children were more susceptible to heavy metals contamination than adults. The inhabitants of the four high Andean zones were exposed to carcinogenic health risks for As through daily intake of native potatoes. The carcinogenic risk for As was greater than the critical value of $1 \times 10^{-4}$. Therefore, it is suggested to carry out a continuous and systematic monitoring of heavy metals in soils and native food crops, especially As, and to study the sources of contamination for implement a soil and crop management program to guarantee the quality of food products.

\section{Acknowledgements}

The authors thank the National University of Central Peru for the financing provided through the canon, on canon and mining royalties for the execution of this investigation. We also thank the inhabitants of the high Andean communities for providing information and facilities in the collection of samples. To Fanny Cencia Hilario and Alexis Limas Quispe for collaborating in the collection of study samples.

\section{Conflicts of Interest}

The authors declare no conflicts of interest regarding the publication of this paper.

\section{References}

[1] Rehman, Z.U., Khan, S., Shah, M.T., Brusseau, M.L., Khan, S.A. and Mainhagu, J. 
(2018) Transfer of Heavy Metals from Soils to Vegetables and Associated Human Health Risk in Selected Sites in Pakistan. Pedosphere: An International Journal, 28, 666-679. https://doi.org/10.1016/S1002-0160(17)60440-5

[2] Musilova, J., Bystricka, J., Vollmannova, A., Janotova, B., Orsak, M., Harangozo, L. and Hegedusova, A. (2017) Safety of Potato Consumption in Slovak Region Contaminated by Heavy Metals Due to Previous Mining Activity. Journal of Food Quality, 2017, Article ID: 9385716. https://doi.org/10.1155/2017/9385716

[3] Gu, Y.G., Li, Q.S., Fang, J.H., He, B.Y., Fu, H.B. and Tong, Z.J. (2014) Identification of Heavy Metal Sources in the Reclaimed Farmland Soils of the Pearl River Estuary in China Using a Multivariate Geostatistical Approach. Ecotoxicology and Environmental Safety, 105, 7-12. https://doi.org/10.1016/j.ecoenv.2014.04.003

[4] Khan, S., Cao, Q., Zheng, Y.M., Huang, Y.Z. and Zhu, Y.G. (2008) Health Risks of Heavy Metals in Contaminated Soils and Food Crops Irrigated with Wastewater in Beijing, China. Environmental Pollution, 152, 686-692.

https://doi.org/10.1016/j.envpol.2007.06.056

[5] Zhao, Q., Wang, Y., Cao, Y., Chen, A., Ren, M., Ge, Y., Yu, Z., Wan, S., Hu, A., Bo, Q., Ruan, L., Chen, H., Qin, S., Chen, W., Hu, C., Tao, F., Xu, D., Xu, J., Wen, L. and Li, L. (2014) Potential Health Risks of Heavy Metals in Cultivated Topsoil and Grain, Including Correlations with Human Primary Liver, Lung and Gastric Cancer, in Anhui Province, Eastern China. Science of the Total Environment, 470-471, 340-347. https://doi.org/10.1016/j.scitotenv.2013.09.086

[6] Tiller, K.G. (1989) Heavy Metals in Soils and Their Environmental Significance. In: Advances in Soil Science, Springer, Berlin, 113-142. https://doi.org/10.1007/978-1-4612-3532-3_2

[7] Ahmad, K., Khan, Z.I., Ashfaq, A., Ashraf, M., Akram, N.A., Sumaira, Y. and Sher, M. (2015) Assessment of Heavy Metals and Metalloids in Solanum Tuberosum and Pisum Sativum Irrigated with Urban Wastewater in the Suburbs of Sargodha. $\mathrm{Hu}$ man and Ecological Risk Assessment. An International Journal, 21, 1109-1122. https://doi.org/10.1080/10807039.2014.962344

[8] Couto, R.R., Faversani, J., Ceretta, C.A., Ferreira, P.A.A., Marchezan, C., Basso Facco, D., Garlet, L.P., Silva, J.S., Comin, J.J., Bizzi, C.A., Flores, E.M.M. and Brunetto, G. (2018) Health Risk Assessment and Soil and Plant Heavy Metal and Bromine Contents in Field Plots after Ten Years of Organic and Mineral Fertilization. Ecotoxicology and Environmental Safety, 153, 142-150. https://doi.org/10.1016/j.ecoenv.2018.01.046

[9] Yang, X., Li, Q., Tang, Z., Zhang, W., Yu, G., Shen, Q. and Zhao, F.J. (2017) Heavy Metal Concentrations and Arsenic Speciation in Animal Manure Composts in China. Waste Management, 64, 333-339. https://doi.org/10.1016/j.wasman.2017.03.015

[10] Defarge, N., Spiroux de Vendomois, J.D. and Séralini, G.E. (2018) Toxicity of Formulants and Heavy Metals in Glyphosate-Based Herbicides and Other Pesticides. Toxicology Reports, 5, 156-163. https://doi.org/10.1016/j.toxrep.2017.12.025

[11] Ali, H. and Khan, E. (2018) Trophic Transfer, Bioaccumulation and Biomagnification of Non-Essential Hazardous Heavy Metals and Metalloids in Food Chains/Webs-Concepts and Implications for Wildlife and Human Health. Human and Ecological Risk Assessment, 25, 1353-1376. https://doi.org/10.1080/10807039.2018.1469398

[12] Gall, J.E., Boyd, R.S. and Rajakaruna, N. (2015) Transfer Heavy Metals through Terrestrial Food Webs: A Review. Environmental Monitoring and Assessment, 187, Article No. 201. https://doi.org/10.1007/s10661-015-4436-3

[13] Bian, B., Lin, C. and Lv, L. (2016) Health Risk Assessment of Heavy Metals in 
Soil-Plant System Amended with Biogas Slurry in Taihu Basin, China. Environmental Science and Pollution Research, 23, 16955-16964. https://doi.org/10.1007/s11356-016-6712-3

[14] Chen, Y., Yuan, L. and Xu, C. (2018) The Accumulation Characteristics and Potential Health Risks of Heavy Metals in Vegetables from Reclaimed Area of China. Human and Ecological Risk Assessment. An International Journal, 24, 949-960. https://doi.org/10.1080/10807039.2017.1403281

[15] Khan, K., Khan, H., Lu, Y., Ihsanullah, I. and Nawab, J. (2014) Evaluation of Toxicological Risk of Foodstuffs Contaminated with Heavy Metals in Swat, Pakistan. Ecotoxicology and Environmental Safety, 108, 224-232. https://doi.org/10.1016/j.ecoenv.2014.05.014

[16] Wang, Z., Meng, B., Zhang, W., Bai, J., Ma, Y. and Liu, M. (2018) Multi-Target Risk Assessment of Potentially Toxic Elements in Farmland Soil Based on the Environment-Ecological-Health Effect. International Journal of Environmental Research and Public Health, 15, 1-14. https://doi.org/10.3390/ijerph15061101

[17] Khan, A., Khan, S., Khan, M.A., Qamar, Z. and Waqas, M. (2015) The Uptake and Bioaccumulation of Heavy Metals by Food Plants, their Effects on Plants Nutrients, and Associated Health Risk: A Review. Environmental Science and Pollution Research, 22, 13772-13799. https://doi.org/10.1007/s11356-015-4881-0

[18] Ministerio de Agricultura y Riego (MINAGRI), Grupo Yanapai, Instituto Nacional de Innovación Agraria (INIA), C. I. de la P. (CIP) (2017) Catálogo de Variedades de Papa Nativa al Sureste del Departamento de Junín-Perú. 117.

[19] Meinzen-Dick, R.S., Devaux, A. and Antezana, I. (2009) Underground Assets: Potato Biodiversity to Improve the Livelihoods of the Poor. International Journal of Agricultural Sustainability, 7, 235-248. https://doi.org/10.3763/ijas.2009.0380

[20] Devaux, A. (2018) Tecnología e Innovaciones de Papa como Puente Crítico para Responder a los Desafíos de Seguridad Alimentaria y Promover los Agronegocios en América Latina. Revista Latinoamericana de la Papa, 22, 5-9. https://doi.org/10.37066/ralap.v22i1.295

[21] Bradshaw, J.E. and Ramsay, G. (2009) Potato Origin and Production. In: Advances in Potato Chemistry and Technology, Academic Press, Burlington, 1-26. https://doi.org/10.1016/B978-0-12-374349-7.00001-5

[22] Khan, Z.I., Ahmad, K., Yasmeen, S., Aisha, N., Ashraf, M. and Mehmood, N. (2017) Potential Health Risk Assessment of Potato (Solanum tuberosum L.) Grown on Metal Contaminated Soils in The Central Zoneof Punjab, Pakistan. Chemosphere, 166, 157-162. https://doi.org/10.1016/j.chemosphere.2016.09.064

[23] Peng, Y., Yang, R., Jin, T., Chen, J. and Zhang, J. (2018) Risk Assessment for Potentially Toxic Metal (Loid)s in Potatoes in the Indigenous Zinc Smelting Area of Northwestern Guizhou Province, China. Food and Chemical Toxicology, 120, 328-339. https://doi.org/10.1016/j.fct.2018.07.026

[24] Musilová, J., Bystrická, J., Vollmannová, A. and Melicháčová, S. (2011) Contamination of Potato Tubers by Heavy Metals and Their Influence on the Formation of Phenolic Substances. Journal of Central European Agriculture, 12, 433-444. https://doi.org/10.5513/JCEA01/12.3.936

[25] Chen, Z., Zhao, Y., Gu, L., Wang, S., Li, Y. and Dong, F. (2014) Accumulation and Localization of Cadmium in Potato (Solanum tuberosum) under Different Soil Cd Levels. Bulletin of Environmental Contamination and Toxicology, 92, 745-751. https://doi.org/10.1007/s00128-014-1252-3

[26] Orellana, E. and Erazo, R. (2017) Environmental Risk of Lead Accumulation in 
Crops Irrigated with Water from the Mantaro River, Jauja Sector, Perú. In: Ecotoxicology in Latin America, Nova Science, New York, 363-376.

[27] Loayza-Muro, R. (2016) Daños Ambientales de la Minería en el Perú: Qué Hacer con Ellos? Metas del Perú al bicentenario, 336.

http://www.consorcio.edu.pe/metas-bicentenario/Metas-del-Peru-al-Bicentenario-C onsorcio-de-Universidades-Libro-Digital.pdf

[28] Rodriguez, R., Oldecop, L., Linares, R. and Salvado, V. (2012) Los Grandes Desastres Medioambientales Producidos por la Actividad Minero-Metalúrgica a Nivel Mundial: Causas y Consecuencias Ecológicas y Sociales. Revista del Instituto de Investigación FIGMMG, 12, 7-25.

[29] USEPA (2007) Microwave Assisted Acid Digestion of Sediments, Sludges, Soils and Oils. https://www.epa.gov/sites/production/files/2015-12/documents/3051a.pdf

[30] Chen, L., Zhou, S., Shi, Y., Wang, C., Li, B., Li, Y. and Wu, S. (2018) Heavy Metals in Food Crops, Soil, and Water in the Lihe River Watershed of the Taihu Region and Their Potential Health Risks When Ingested. Science of the Total Environment, 615, 141-149. https://doi.org/10.1016/j.scitotenv.2017.09.230

[31] Cui, Y.J., Zhu, Y.G., Zhai, R.H., Chen, D.Y., Huang, Y.Z., Qiu, Y. and Liang, J.Z. (2004) Transfer of Metals from Soil to Vegetables in an Area near a Smelter in Nanning, China. Environment International, 30, 785-791. https://doi.org/10.1016/j.envint.2004.01.003

[32] Zhang, Y., Yin, C., Cao, S., Cheng, L., Wu, G. and Guo, J. (2017) Heavy Metal Accumulation and Health Risk Assessment in Soil-Wheat System under Different Nitrogen Levels. Science of the Total Environment, 622-623, 1499-1508. https://doi.org/10.1016/j.scitotenv.2017.09.317

[33] Jia, Z., Li, S. and Wang, L. (2018) Assessment of Soil Heavy Metals for Eco-Environment and Human Health in a Rapidly Urbanization Area of the Upper Yangtze Basin. Scientific Reports, 8, Article No. 3256. https://doi.org/10.1038/s41598-018-21569-6

[34] Rehman, Z.U., Khan, S., Brusseau, M.L. and Shah, M.T. (2016) Lead and Cadmium Contamination and Exposure Risk Assessment via Consumption of Vegetables Grown in Agricultural Soils of Five-Selected Regions of Pakistan. Chemosphere, 168, 1589-1596. https://doi.org/10.1016/j.chemosphere.2016.11.152

[35] USEPA (1989) Risk Assessment Guidance for Superfund. Volume I. Human Health Evaluation Manual (Part A). https://rais.ornl.gov/documents/HHEMA.pdf

[36] USEPA (2001) Risk Assessment Guidance for Superfund (RAGS) Volume III Part A: Process for Conducting Probabilistic Risk Assessment.

http://www.epa.gov/sites/production/files/2015-09/documents/rags3adt_complete.p df

[37] Khan, K., Lu, Y., Khan, H., Zakir, S., Khan, S., Khan, A.A., Wei, L. and Wang, T. (2013) Health Risks Associated with Heavy Metals in the Drinking Water of Swat, Northern Pakistan. Journal of Environmental Sciences, 25, 2003-2013. https://doi.org/10.1016/S1001-0742(12)60275-7

[38] Somda, M.K., Kabore, D., Mogmenga, I., Ouattara, C.A.T., Ouattara, A., Dabire, Y., Nikiema, M., Mihin, H.B., Akakpo, A.Y., Ouedraogo, O., Traore, A.S. and Ouattara, A.S. (2019) Health Risk Assessment of Heavy Metals and Microbial Quality of Local Tomato (Solanum lycopersicum) of Ouagadougou, Burkina Faso. Journal of Environmental Protection, 10, 942-957. https://doi.org/10.4236/jep.2019.107056

[39] Bamuwamye, M., Ogwok, P. and Tumuhairwe, V. (2015) Cancer and Non-Cancer Risks Associated with Heavy Metal Exposures from Street Foods: Evaluation of 
Roasted Meats in an Urban Setting. Journal of Environment Pollution and Human Health, 3, 24-30.

[40] Huang, M., Zhou, S., Sun, B. and Zhao, Q. (2008) Heavy Metals in Wheat Grain: Assessment of Potential Health Risk for Inhabitants in Kunshan, China. Science of the Total Environment, 405, 54-61. https://doi.org/10.1016/j.scitotenv.2008.07.004

[41] Ametepey, S.T., Cobbina, S.J., Akpabey, F.J., Duwiejuah, A.B. and Abuntori, Z.N. (2018) Health Risk Assessment and Heavy Metal Contamination Levels in Vegetables from Tamale Metropolis, Ghana. International Journal of Food Contamination, 5, Article No. 5. https://doi.org/10.1186/s40550-018-0067-0

[42] USEPA IRIS (2019) Integrated Risk Information System (IRIS). Regional Screening Levels (RSLs)—Generic Tables (November 2019).

https://www.epa.gov/risk/regional-screening-levels-rsls-generic-tables

[43] Song, D., Zhuang, D., Jiang, D., Fu, J. and Wang, Q. (2015) Integrated Health Risk Assessment of Heavy Metals in Suxian County, South China. International Journal of Environmental Research and Public Health, 12, 7100-7117. https://doi.org/10.3390/ijerph120707100

[44] Edogbo, B., Okolocha, E., Maikai, B., Aluwong, T. and Uchendu, C. (2020) Risk Analysis of Heavy Metal Contamination in Soil, Vegetables and Fish around Challawa Area in Kano State, Nigeria. Scientific African, 7, e00281. https://doi.org/10.1016/j.sciaf.2020.e00281

[45] Mao, C., Song, Y., Chen, L., Ji, J., Li, J., Yuan, X., Yang, Z., Ayoko, G.A., Frost, R.L. and Theiss, F. (2019) Human Health Risks of Heavy Metals in Paddy Rice Based on Transfer Characteristics of Heavy Metals from Soil to Rice. Catena, 175, 339-348. https://doi.org/10.1016/j.catena.2018.12.029

[46] Ministerio del Ambiente (MINAM) (2017) Aprueban Estandares de Calidad Ambiental para Suelo. D. S. N 011-2017-MINAM. 2 de diciembre del 2017. http://www.minam.gob.pe/wp-content/uploads/2017/12/DS_011-2017-MINAM.pdf

[47] Liu, W.-R., Zeng, D., She, L., Su, W.-X., He, D.-C., Wu, G.-Y., Ma, X.-R., Jiang, S., Jiang, C.-H. and Ying, G.-G. (2020) Comparisons of Pollution Characteristics, Emission Situations and Mass Loads for Heavy Metals in the Manures of Different Livestock and Poultry in China. Science of the Total Environment, 734, Article ID: 139023. https://doi.org/10.1016/j.scitotenv.2020.139023

[48] Mirzaei Aminiyan, M., Baalousha, M., Mousavi, R., Mirzaei Aminiyan, F., Hosseini, H. and Heydariyan, A. (2018) The Ecological Risk, Source Identification and Pollution Assessment of Heavy Metals in Road Dust: A Case Study in Rafsanjan, SE Iran. Environmental Science and Pollution Research, 25, 13382-13395. https://doi.org/10.1007/s11356-017-8539-y

[49] FAO/WHO (2015) General Standard for Contaminants and Toxins in Food and Feed (Codex Stan 193-1995). www.fao.org/input/download/standards/17/CXS_193e_2015.pdf

[50] Sanderson, D.V., Voutchkov, M. and Benkeblia, N. (2019) Bioaccumulation of Cadmium in Potato Tuber Grown on Naturally High Levels Cadmium Soils in Jamaica. Science of the Total Environment, 649, 909-915. https://doi.org/10.1016/j.scitotenv.2018.08.220

[51] Kabata-Pendias, A. (2011) Trace Elements in Soils and Plants. CRC Press, Boca Raton. https://doi.org/10.1201/b10158

[52] Yang, J., Ma, S. and Zhou, J. (2018) Heavy Metal Contamination in Soils and Vegetables and Health Risk Assessment of Inhabitants in Daye, China. Journal of International Medical Research, 46, 3374-3387. 
https://doi.org/10.1177/0300060518758585

[53] FAO/WHO (1982) Evaluation of Certain Food Additives and Contaminants. 59. https://apps.who.int/iris/handle/10665/41546

[54] FAO/WHO (2011) Safety Evaluation of Certain Food Additives and Contaminants. Lead. 381-497.

http://apps.who.int/food-additives-contaminants-jecfa-database/chemical.aspx?che $\underline{\mathrm{mID}=3511}$

[55] FAO/WHO (2011) Safety Evaluation of Certain Contaminants in Food. Arsenic. 153-316.

https://apps.who.int/food-additives-contaminants-jecfa-database/chemical.aspx?che $\mathrm{mID}=1863$

[56] Obiora, S.C., Chukwu, A., Chibuike, G. and Nwegbu, A.N. (2019) Potentially Harmful Elements and Their Health Implications in Cultivable Soils and Food Crops around Lead-Zinc Mines in Ishiagu, Southeastern Nigeria. Journal of Geochemical Exploration, 204, 289-296.

[57] Liu, Y.M., Liu, D.Y., Zhang, W., Chen, X.X., Zhao, Q.Y., Chen, X.P. and Zou, C.Q. (2020) Health Risk Assessment of Heavy Metals ( $\mathrm{Zn}, \mathrm{Cu}, \mathrm{Cd}, \mathrm{Pb}, \mathrm{As}$ and $\mathrm{Cr}$ ) in Wheat Grain Receiving Repeated Zn Fertilizers. Environmental Pollution, 257, Article ID: 113581.

[58] ATSDR (2019) Toxicological Profile for Lead. https://www.atsdr.cdc.gov/toxprofiles/tp13.pdf

[59] IARC (2012) Arsenic, Metals, Fibres and Dusts. A Review of Human Carcinogens. https://www.iarc.fr 